\title{
Exchange Rate Determination in Developing Economies
}

\author{
Oluremi Davies Ogun \\ Department of Economics, University of Ibadan, Ibadan, Nigeria \\ Email:1rogun@gmail.com,r_ogun@yahoo.com
}

Received July 19, 2012; revised August 17, 2012; accepted August 25, 2012

\begin{abstract}
This paper identifies the determinants of nominal exchange rate movements in less developed countries operating the flexible exchange rate system. Factors peculiar to such countries which are believed to potently drive their nominal exchange rates are incorporated into the resulting model. In particular, the weather, parallel market exchange rate and its associated premium as well as corrupt practices enter the model. While all four factors should play crucial roles in explaining short-run variations in the exchange rate, corrupt practices may still be at work in the long-run. However, those more advanced developing countries that have succeeded in instituting a relatively more effective legal system stemming the tide of corruption, and, also characterized by a near absence of parallel exchange rate market, may follow the standard model of exchange rate in the literature.
\end{abstract}

Keywords: Purchasing Power Parity; Parallel Market Exchange Rate; Parallel Market Exchange Rate Premium; Corruption

\section{Introduction}

Either on its own or in terms of its linkage with the real exchange rate (RER), the nominal exchange rate represents a powerful economic policy tool as it influences resource allocation, growth of international trade and structural change. For a market economy, it is about the most important relative price influencing practically all other prices. Thus, it deserves utmost attention especially, in matters of determination.

The theoretical literature on the determination of nominal exchange rate recognizes the influence of international trade and payments, speculation and hedging activities. Due however to the peculiar circumstance of most developing countries (being mostly agrarian and with a lax legal system for examples), some factors that enter into their exchange rate determination processes may be distinct. The aim in this paper is to highlight such subtle distinctions. Section 2 below provides a brief review of the theoretical literature while Section 3 deals with the rate determination model. Section 4 gives some concluding remarks.

\section{Related Literature}

Four approaches to nominal exchange rate determination are prominent in the literature (see e.g. Isard [1], MacDonald and Taylor [2], Taylor [3]). They are the traditional model, the monetary model, the portfolio balance approach and the purchasing power parity model. The models are briefly discussed below only in the context of flexible exchange rate system.

In the traditional model, forces of supply of, and demand for foreign exchange play crucial roles in the determination of the equilibrium rate which emerges at the equality of the supply of and the demand for foreign exchange. Capital flows perform important function in maintaining equilibrium in this model with an outflow moderating current account surplus and an inflow easing (financeing) current account deficit. In order to prevent excessive changes in the exchange under this approach, attention is usually paid to the determinants of the changes in the current account which are, relative prices and income. Accordingly, a situation of current account deficit which tends to depreciate the exchange rate calls for concerted effort at reducing both domestic price level and income while raising interest rate. However, the seeming over-concern with policy actions to induce capital flows to finance disequilibrium carries with it the implication of a passive assumption that the asset market simply follows the policy dictates of the deficit country. Quite clearly, independent actions from foreign bond holders could throw a monkey wrench in the works.

The monetary model is similar to the traditional model in the sense of relying on market forces albeit in the money market to determine the equilibrium exchange rate. Under this setting, the exchange rate adjusts to accommodate any disequilibrating development in the money market. For example, monetary expansion which could produce an excess supply of money would also cause price 
level to rise leading to exchange rate depreciation. However, the level of wealth also increases causing the purchase of financial assets (including, foreign assets) to rise which in turn generates an increase in the demand for money. Ultimately, the excess supply of money would be mopped up and the exchange rate returns to its original level in the long-run (see e.g. Frenkel [4], Frenkel and Mussa [5] and Machlup [6]). Thus, given flexible exchange rate system, any disequilibrium in the money market is short-lived and the exchange rate only changes temporarily to accommodate this development otherwise, balance of payments deficit would result. Pressure for such (self reversing) short-run movements in the exchange rate could also come from changes in interest rate and income. The only drawback to this approach is that it assumes unrealistically that the domestic and foreign financial assets are perfect substitutes; this may be a source of persistent disequilibrium under the model.

The Portfolio Balance approach views the exchange rate as resulting from a process of financial equilibrium in the economy. Such financial equilibrium results from a simultaneous equilibrium in the individual financial asset markets, that is, when the amount of each asset desired to be held is the amount that is actually held. Three of such markets are considered crucial here, domestic money or monetary base, domestic bonds and foreign bonds. Three equilibrium prices emerge from the attainment of this financial equilibrium: equilibrium price of each asset, the equilibrium interest rate in the country and the equilibrium exchange rate. The exchange rate emerges from this model because any portfolio switches between the domestic assets and the foreign asset necessitates new demand for foreign exchange (Appleyard et al. [7]). However, it has been noted that the approach disregards the fundamentals of trade in its calculations (Ojo [8]) and, this may be a source of inexplicable changes in the exchange rate.

The Purchasing Power Parity (PPP) doctrine seeks to identify the true equilibrium rate that would ensure simultaneous attainment of current and capital account balances. It exists in two versions, an absolute version and a relative version. In a general context, the PPP postulates that the price of any given commodity remains the same in all countries when measured in the same currency. It is therefore sometimes referred to as the law of one price (LOOP) under which arbitrage plays an important role in effecting the price parity across geographical locations. Notwithstanding the infraction to this law often engendered by transportation and handling charges, it is generally believed that the law is plausible. Accordingly, the absolute PPP stipulates that the absolute level of the exchange rate is that which causes traded goods and ser-

\footnotetext{
${ }^{1}$ The influence of hedging in the domestic economy is in this model subsumed under speculation.
}

vices to have the same price in all countries when measured in the same currency. There is however very little empirical support for the absolute PPP due to the rather strong influence of transportation costs and trade barriers at keeping prices from equalising across geographical locations, and the effect of the differences in the composition and relative importance of various goods on each country's price level determination (Appleyard et al. [7], Rogoff [9]). As a result, the relative PPP is often resorted to for operational concept. Under this version, the equilibrium rate equals an initial period (base year) exchange rate multiplied by the ratio of the price indices of the domestic and foreign countries. In this way, the relative PPP only captures an implicit rate, the real exchange rate, and it is thus not particularly useful in the analysis of the movements in the explicit rate, the nominal exchange rate.

\section{The Model}

This model describes the determination of the nominal exchange rate in a developing country operating the flexible exchange rate system. The nominal exchange rate (NER) is the price of foreign currency in units of domestic currency. It is assumed to be determined in the same way as the prices of commodities that is, by the forces of the market albeit, in the foreign exchange market. Thus, there is a demand component, a supply component and an equilibrium segment.

Broadly, the demand for foreign exchange (D) is influenced by three factors: changes in the level of imports (M), capital outflow in the form of transfer payments, grants and loans, overseas investments (Co) and speculation $(\mathrm{Sp})^{1}$. Thus,

$$
\mathrm{D}=\mathrm{D}(\mathrm{M}, \mathrm{Co}, \mathrm{Sp})
$$

Changes in the level of imports would be a function of changes in domestic price level $(\pi)$, and income (Y). Capital outflow would be influenced by the quest for overseas investment by governments and residents and this quest would be a function of foreign income $\left(\mathrm{Y}^{*}\right)$ and relative inflation rates $\left(\pi-\pi^{*}\right)$ as well as capital flight. Capital flight can be simply expressed as a function of interest rate differential $\left(\mathrm{i}-\mathrm{i}^{*}\right)$ and socio-economic instability that can be represented by fiscal deficit (FD) and corrupttion (C) which in turn can be proxy by corruption perception index. Under a dual exchange rate system, the parallel market exchange rate premium (PMP) would also qualify as a proxy for corruption. Speculation can be narrowed to the existence of parallel market exchange rate (PMR) or its premium (PMP), so that we write ${ }^{2}$,

\footnotetext{
${ }^{2}$ Since by assumption, the model relates to an economy operating the flexible exchange rate system, speculative activities of the type of leads and lags are minimal in the absence of any expected major currency realignment policy as could happen under a fixed exchange rate system and its variants.
} 


$$
\mathrm{D}=\mathrm{D}\left(\pi, \mathrm{Y}, \mathrm{Y}^{*}, \pi-\pi^{*}, \mathrm{i}-\mathrm{i}^{*}, \mathrm{FD}, \mathrm{C}, \mathrm{PMR}, \mathrm{PMP}\right)
$$

with all partials expected to be positive.

On the other hand, the supply of foreign exchange (S) will be a function of changes in exports $(\mathrm{X})$, foreign investments (FI), changes in foreign reserves (R) as well as speculation and hedging activities of foreigners ( $\mathrm{Sh}$ ) such that we can write,

$$
\mathrm{S}=(\mathrm{X}, \mathrm{Fi}, \mathrm{R}, \mathrm{Sh})
$$

Changes in export will be a reflection of the international price of export items $\left(\mathrm{P}_{\mathrm{T}}^{\mathrm{E}}\right)$ and weather condition in the domestic economy which can be proxy by a trend variable (TT) reflecting the difference between actual and trend real agricultural output. Foreign investment would be influenced by general reform climate which can simply be represented by the real exchange rate (RER). Changes in foreign reserves would be a result of changes in the balances on both current and capital accounts which are in turn influenced by price level changes, income, international price of exports, weather conditions and interest rate differentials. Speculation and hedging activities of foreigners would be influenced by parallel market exchange rate (PMR), inflation differentials $\left(\pi-\pi^{*}\right)$, interest rate differentials $\left(i-i^{*}\right)$ and the size of the stock market represented by its market capitalization (MK). Thus, we have that,

$$
\mathrm{S}=\mathrm{S}\left(\pi, \mathrm{Y}, \mathrm{P}_{\mathrm{T}}^{\mathrm{E}}, \mathrm{TT}, \pi-\pi^{*}, \mathrm{i}-\mathrm{i}^{*}, \mathrm{MK}, \mathrm{RER}, \mathrm{PMR}\right)
$$

Except for $\pi-\pi^{*}$ and PMR, all partials are expected to be positive.

Incorporating income differential to track the effect of long-run capital flows, equilibrium NER equation would result from the net of Equations (2) and (4) such that,

\footnotetext{
${ }^{3}$ The marked difference in the definitions of the parallel market exchange rate and the parallel market exchange rate premium, should reduce the possibility of multicollinearity from their joint presence in the equation. The premium could for example be defined as the percentage excess of the parallel market rate over the official rate (see e.g. Dornbusch et al. [10]). ${ }^{4}$ Foreign income does not enter the equilibrium equation independently because the motives for its entry are already captured by interest rate differentials and stock market capitalization. Where there is a compelling urge to include foreign income in Equation (5) as part of the demand drivers for export hence, source of supply of foreign exchange, the nature of exported items (that is, whether they are luxuries or necessities to the importer country) should be considered instead.

${ }^{5}$ There are other forms of corrupt practices which though do not end up in capital flight also exert appreciating influence on the exchange rate through the related parallel market rate and premium. An example is the well-known practice of round-tripping by banks under which they bid for and purchase foreign exchange at the auction (autonomous market's) rate but end up selling at the parallel market at that market's rate. Government agencies are sometimes accomplices in this act as they specially arrange for sizable government funds to be placed on deposits with these banks and thus increase the banks' and the agencies' profit from such round-tripping business. Overall, the reduced supply in the conventional market raises the inter-bank rate and the autonomous market's rate both of which could put upward pressure on the official rate; the bureaux de change and the parallel market rates similarly benefit from the increase in the patronage of the related markets.
}

$$
\begin{array}{r}
\mathrm{E}=\mathrm{E}\left(\pi-\pi^{*}, \mathrm{Y}, \mathrm{Y}-\mathrm{Y}^{*}, \mathrm{P}_{\mathrm{T}}^{\mathrm{E}}, \mathrm{TT}, \mathrm{i}-\mathrm{i}^{*},\right. \\
\text { FD,C,MK, RER, PMR,PMP })^{3}
\end{array}
$$

Apart from inflation differential $\left(\pi-\pi^{*}\right)$, fiscal deficit (FD), parallel market exchange rate (PMP) and the parallel market exchange rate premium (PMP) whose changes would produce a depreciating effect on the exchange rate, all other variables' partials are expected to be positive ${ }^{4}$.

Four variables, TT (trend variable capturing the influence of weather condition), C (corruption), PMR (parallel market exchange rate) and PMP (parallel market exchange rate premium) appear to be peculiar to the typical developing economy. Corruption exists in almost all countries of the world but the nature and manner of occurrence of the vice in developing countries are such that, it generates serious adverse consequences for the growth of such economies in the short-run (see e.g. Asiedu and Freeman [11], Anorou and Braha [12]) and the long-run too (see e.g. Dissou and Yakautsava [13] and Ogun [14]). To escape detection and legal or political restitution of the looted treasury funds, such funds often take on the nature of capital flight. Thus, unlike in most advanced countries, such looted funds hardly contribute meaningfully to economic activities in the typical developing country ${ }^{5}$.

Furthermore, in the course of their flight, the looted funds often produce new distortions or reinforce existing distortions especially, in relative prices, in the economy. In most cases, the parallel exchange rate market is patronized with the associated rate rising significantly, thereby, putting upward pressure on the related parallel market premium as the main market exchange rate (and the inter-bank rate too) depreciates. It was reported in Ogun [15] that the explosion in commodity prices witnessed in the late 1980s (the early years of the switch from fixed to flexible exchange rate system) in Nigeria was due to the incidence of capital flight. The parallel market rate and premium were also joint beneficiaries ${ }^{6}$.

In general, while the effects of PMR, PMP and the weather on nominal exchange rate should be expected to wear off in the long-run ${ }^{7}$, that of corruption may still be active in the same run ${ }^{8}$. However, some of the more advanced developing countries may be spared the influence of these additional variables. Usually, such countries are not capital (including, foreign exchange) scarce, hence, the incentive for a thriving parallel exchange rate market

\footnotetext{
${ }^{6}$ Incidences of leads and lags hedging practice may have been contributory to the emergent exchange rates but were in this particular instance, indistinguishable from the broad play of capital flight.

${ }^{7}$ Prolonged adverse weather condition would usually elicit policy response to mitigate its macroeconomic effects.

${ }^{8}$ Two variables in the standard model, inflation differential and income or real income (or its growth) - the latter as a proxy for productivity growth, could similarly exert long-run effect. Other long-run factors though not written into the model include, taste (that is, preference for domestic or foreign goods) and, tariffs and quotas. For further details on these additional long-run determinants, see for example, Mishkin [16].
} 
is almost non-existent. In addition, they have mostly succeeded in instituting a relatively effective legal system helping to stem the tide of corrupt practices. Thus, such economies are more likely to be accurately represented by the standard exchange rate determination model in the literature.

\section{Conclusion}

Existing models of nominal exchange rate determination in the literature mostly ignores the peculiar developments in developing countries and therefore inaccurately describes the modalities of short run movements in these countries' nominal exchange rate. This paper rectified this oversight by developing a model which accommodates those crucial but unconventional determinants of the nominal exchange rate in the typical developing economy. Factors such as weather condition, the existence of parallel market exchange rate, its associated premium and corrupt practices are identified to be critical drivers of short term variations in the nominal exchange rate. Even, in the long-run, a factor such as corruption could still be playing very important roles. It should however be understood that only particular types of developing countries' exchange rate dynamics would be explained by this model. Some advanced developing countries may have developed a more effective legal system curtailing corrupt practices. Such countries' exchange rate system may also be devoid of the sharp parallel market practices bestriding the less advanced developing countries' exchange rate system. In this case, the standard modelling approach noted in the introductory section would be more applicable.

\section{REFERENCES}

[1] P. Isard, "Exchange Rate Economics: Survey of Economic Literature," Cambridge University Press, Cambridge, 1995.

[2] R. MacDonald and M. P. Taylor, "The Monetary Model of the Exchange Rate: Long-Run Relationships, ShortRun Dynamics and How to Beat a Random Walk," Journal of International Money and Finance, Vol. 13, No. 3, 1994, pp. 276-290. doi:10.1016/0261-5606(94)90029-9

[3] M. P. Taylor, "The Economics of Exchange Rates," Journal of Economic Literature, Vol. 33, No. 1, 1995, pp. 1347.
[4] J. A. Frenkel, "A Monetary Approach to the Exchange Rate: Doctrinal Aspects and Empirical Evidence," Scandinavian Journal of Economics, Vol. 78, No. 2, 1976, pp. 200-224.

[5] J. A. Frenkel and M. L. Mussa, "Assets Markets, Exchange Rates and the Balance of Payments," In: R. W. Jones and P. B. Kenen, Eds., Handbook of International Economics, Vol. II, 1985, pp. 679-747. doi:10.1016/S1573-4404(85)02005-6

[6] F. Machlup, "The Theory of Foreign Exchanges," Economica, Vol. 6, No. 24, pp. 375-397. doi: $10.2307 / 2548881$

[7] D. R. Appleyard, A. J. Field Jr. and S. L. Cobb, "International Economics," 5th Edition, McGraw-Hill/Irwin Co., Boston, Chapters 20, 22.

[8] M. O. Ojo, "Principles and Practice of Monetary Management in Nigeria," Central Bank of Nigeria, Abuja, 2001, p. 152.

[9] K. Rogoff, "The Purchasing Power Parity Puzzle," Journal of Economic Literature, Vol. 34, No. 2, 1996, pp. 647-668.

[10] R. Dornbusch, D. V. Dantas, C. Pechman, R. R. Rocha and S. Simoes, "The Black Market for Dollars in Brazil," Quarterly Journal of Economics, Vol. 98, No. 1, 1983, pp. 25-40. doi:10.2307/1885565

[11] E. Asiedu and J. Freeman, "The Effect of Corruption on Investment and Growth: Evidence from Firms in Latin America, Sub-Saharan Africa, and Transition Countries," Review of Development Economics, Vol. 13, No. 2, 2009, pp. 200-214. doi:10.1111/j.1467-9361.2009.00507.x

[12] E. Anorou and H. Braha, "Corruption and Economic Growth: The African Experience," 2005. http://www.jsdafrica.com/Jsda/Spring2005/ArticlePDF/A rc_Corruption\%20and\%20Economic\% 20Growth.pdf

[13] Y. Dissou and T. Yakaustava, "Corruption, Growth and Taxation," Theoretical Economics Letters, Vol. 2, No. 1, 2012, pp. 62-66. doi:10.4236/tel.2012.21011

[14] O. D. Ogun, "Corruption and Long-Run Growth: A Framework, " Unpublished.

[15] O. D. Ogun, "Nigeria," In: S. M. Wangwe, Ed., Exporting Africa: Technology, Trade and Industrialisation in SubSaharan Africa, UNU/INTECH Studies in New Technology and Development, Routledge, London and New York, 1995, pp. 246-295.

[16] F. S. Mishkin, "The Economics of Money, Banking and Financial Markets," 8th Edition, Addison Wesley Co., Boston, 2007. 